\title{
Исламова А.К. \\ Стратегия глобализации художественного пространства в романе К. Уилсона «Башня
}

(Россия, Санкт-Петербург)

doi: $10.18411 / s r-10-08-2017-15$

idsp: 000001:sr-10-08-2017-15

\section{Аннотация}

В статье устанавливается функциональная зависимость между формированием концептуальной схемы и авторской стратегией ее реализации в эпической перспективе рассматриваемого произведения. Определение онтологических, гносеологических и эстетических концептов схемы сопровождается анализом их содержательных и формообразующих связей с проектом и созданием картины мира и человека в нем в масштабах глобального социума. Итоги предпринятого опыта позволяют заключить, что стратегическая цель глобализации состояла в гуманистическом обосновании результатов прогресса, а средством достижения этой цели явилось изображение индивидуальной судьбы как части всемирно-исторического опыта.

Ключевые слова: Художественное пространство, эпический концепт, концептуальная схема, стратегия глобализации, архитектоника жанровой формы

\section{Abstract}

The article states the functional relation between the formation of the conceptual scheme and the author's strategy of its realization in the epic perspective of the novel "TheTower" by C. Wilson. The ontological, epistemological and aesthetic concepts of the scheme are viewed in the network of their meaningful and formative connections with the creation of the global picture of the world and man in it in the novel considered. The study is followed with the conclusion that the writer's strategy of globalization is aimed at the correlation of natural and human factors of civilization and that this aim is achieved in the novel due to representation of individual life as part the total historic experience.

Keywords: Epic perspective, epic concept, conceptual scheme, strategy of globalization, architectonic of genre form

Английский романист Колин Уилсон вошел в литературу в середине XX века и принял традиции социальной вовлеченности и моральной ответственности писательского труда в качестве ведущих направлений творческого пути. С течением времени его произведения сложились в летопись поворотных событий, включающую философскую оценку общественных конфликтов и гуманистическое обоснование их решений. Опыт междисциплинарных изысканий выразился в научно-публицистических трактатах и эссе, а художественной книгой итогов сталатетралогия «Мир пауков», где автор запечатлел актуальную действительность с позиций пост-современности, иначе - с точки зрения потенциальных угроз и будущих возможностей человеческого бытия. Футурологический проект выполнен в форме эпической полимодели из цикла романов «Башня» (1987), «Дельта» (1987), «Маг» (1992), «Земля теней» (2003). Циклический принцип жанровой организации поддерживается централизованной концептуальной схемой, которая заложена в архитектонику первой книги и задает онтологические, гносеологические и эстетико-художественные концепты всех составных частей.

В романе «Башня» онтологические параметры концептуальной схемы определяются внешними факторами социального и культурного характера. История свидетельствует о том, что в течение двадцатого столетия планетарное сообщество не однажды находилось на грани фатального кризиса, когда извечный вопрос литературы о судьбе человека в мире представал как глобальная проблема выживания в условиях 
беспрецедентных войн, смертельной атомной опасности, стремительной деградации среды обитания вследствие переизбытка и экспансии техники. Обобщая результаты отечественных и зарубежных исследований в области философии глобальных проблем, А.В. Турчин и М.А. Батин подчеркивают: «Каждый из глобальных рисков может охватить всю поверхность Земли настолько быстро, что люди не успеют подготовить средства защиты от него и при этом он обладает такой силой, что может уничтожить каждого человека» [5 c. 197].Очевидные факты катастрофического развития цивилизации составили бытийное основание для разработки прогностического сценария К. Уилсонав масштабах тотального социума: «Все, что необходимо человеческому роду для вхождения в совершенно новую стадию эволюции - это сущностное сознание того, что он, выражаясь образным языком, представляет собой единый организм» [10, p. 236]. Культурные предпосылки онтологического концепта в романе «Башня» были обусловлены, прежде всего, исчерпанностью мировоззрения, в рамках которого социальная и природная реальность могла подвергаться насильственному вторжению со стороны человека в целях ее рационального преобразования. Американский философ Ш. $\mathrm{X}$. Ролстон фиксирует отказ от агрессивного вмешательства в существующий порядок вещей как признак преодоления разрыва между развитием цивилизации и бытием природного мира: «Суть происшедшего изменения - в снятии любого жесткого барьера между человеком и миром» [3, с. 278]. Поддерживая политику ненасильственных компромиссов в области социологии,К. Уилсон особо выделяет их значение для отношений личности с общественным окружением: «Реальная проблема заключается в том, чтобы найти меру единства здорового индивидуализма и здорового общества» $[9, \mathrm{p}$. 49].

Отстранение писателя от прогрессистской установки на переустройство внешнего мира повлекло за собой смещение когнитивного концепта романа «Башня» из сферы объективной реальности в сторону субъекта научного знания и практической деятельности. М. Фуко, представитель постмодернистской философии, полагает, что повышение статуса познающего субъекта является самоочевидной тенденцией новой рациональности, но усматривает в этом явлении гносеологическое искажение пространства науки на пороге классического и современного периодов ее истории: «На этом пороге впервые возникло то странное формообразование знания, которое называют человеком и которое открыло пространство, присущее наукам о человеке» [7, с. 37]. К. Уилсон высказывает противоположное суждение о ценности гуманитарного знания и настаивает на том, что исключение феномена человека из поля исследований чревато нарушением закона объективизма в науке: «Я пришел к тому, что вся моя жизнь была подготовкой к работе, которой я занимаюсь сейчас: открытие новой научной дисциплины, способной одновременно и к подлинной объективности, и к признанию того факта, что человеческие существа и человеческая жизнь сами по себе являются частью загадки» [11, p. 275].Писатель совмещает гуманитарную направленность и эмпирические диспозиции концепта знания за счет внедрения в него эволюционного принципа процесса, а также трактовки человека в качестве объекта и субъекта данного процесса на том основании, что человеческий разум обладает уникальной способностью к «сознательной постановке эволюционной цели» [9, р. 182].

Экстра-литературные предпосылки концептуальной схемы составили достаточно прочный методологический фундамент для создания такой картины человеческой реальности, которая включала бы ее возможность стать иной реальностью. В романе «Башня» заданная цель достигается посредством разработки эстетического плана в жанре философской фантастики, поскольку его формульная структура допускает репрезентацию вероятных ситуаций как несомненных и реальных в границах научной достоверности и художественной условности. Выстраивая эпическую перспективу плана, писатель относит eе хронологические границы к неопределенно далекому будущему и устанавливает пространственные измерения на уровне глобальных значений. Поскольку этот формообразующий конструкт включал в себя прогностическое содержание 
концептуальной схемы, тоее перспективные проекции на эпический горизонт создают облик несчастной планеты, отражающий последствия негативных факторов цивилизации в сюрреалистической картине будущего. Земной пейзаж развертывается здесь как бесплодная пустыня, где обитают гигантские насекомые и страдают преследуемые ими люди: «Сколько люди себя помнили, на них все время охотились. Скорпионы, жукискакуны, полосатые скарабеи, кузнечики-гиганты. Но чаще всех пауки-смертоносцы» [6, c. 9]. По отношению к жанровой архитектонике романа «Башня» и всей эпопеи, сюрреалистическая стилизация первичной экспозиции представляет собой один из способов глобализации художественного пространства, потому что она позволяет соединить детальное описание вводной сцены с универсальной мифологической энигмой - загадкой о происхождении тех таинственных сил, которые властвуют над природой и человеком.

Прослеживая становление фантазийных жанров, Е.Н. Ковтун находит их истоки в глубокой древности, когда мифологический вымысел определял законы построения форм в словесном творчестве: «Изучение этих законов невозможно без учета происхождения вымысла, который, подобно искусству в целом, уходит корнями в первобытную мифологию, сохраняя, нередко, более отчетливо, чем вся остальная литература, связь с мифологическими принципами осмысления и отражения человеческого бытия» [4, с. 33]. В фантастическом романе «Башня» гено́м мифологических коннотаций привносится в структуру пространственной формы при посредничестве центрального персонажа, который прокладывает дорогу жизни в окружающем мире, развертывая эпическое полотно и осмысляя открывающиеся вещи реальности в их значении для человека. Описывая этот путь по образцам мифологических сказов о деяниях великих подвижников, автор романа традиционно наделяет героический образ-характер необычайными свойствами, но отступает от архаических понятий о них. В семиотической теории Р. Барта понятийное наполнение мифа подвержено историческим изменениям в рамках аутентичной идеографической формы: «Миф есть истая идеографическая система, где формы еще монтированы представляемым им понятием, но отнюдь не покрывают им всей своей изобразительной целостности» [1, с. 287] Приведенное суждение вполне применимо к определению функциональной зависимости мифологического прообраза от жанровой формулы современной фантастики в романе «Башня», потому что здесь высшими мерами героических достоинств являются не воинские доблести, а выдающиеся способности ума, многократно превышающие возможности обыденного сознания. Автор выдвигает на передний план обладателя таких качеств и доверяет ему разгадку тайны мира пауков: «Смертоносцы, скажем, покорили человечество оттого, что познали людские умы. Получается, что и человек, познав сущность паучьего разума, сможет одержать когда-нибудь верх над смертоносцами!» [6, с. 103].

С продвижением главного героя по имени Найл в центр эпической перспективы проблема судеб человечества приобретает личностное измерение, а путь жизни протагониста и поле-горизонт его сознания становятся множителями художественного пространства. В сложившейся системе координат, стратегия глобализации направляется на изображение индивидуального бытия как части всемирно-исторического опыта. Эта цель достигается при помощи многообразного набора писательских инструментов, включая описание жизненных обстоятельств текущего времени в свете событий минувших эпох. Отдельные фрагменты исторической ретроспективы восстанавливаются в процессе вторичной экспозиции, когда герой обнаруживает в окрестностях следы древней цивилизации и приходит к признанию былого могущества человеческого рода под впечатлением от различных памятников старины, а более всего - великолепной Белой башни, известной в народе как неприступный и таинственный «ментальный за́мок». Расстановка дальних исторических вех совмещается с обозначением относительно недавних поворотных событий, которые привели большинство людей в рабство к смертоносцам и возвратили других к первобытному состоянию в пустынных или подземных резервациях. Разметка нового участка историографической карты 
осуществляется по свидетельству старейшины рода о том, что роковой поворот начался с Великой Измены, когда правящая элита выдала паукам секреты человеческого разума из корыстных побуждений и обрекла своих собратьев на медленную деградацию и смерть: «Оказывается, между людьми и пауками шла долгая и жестокая борьба, и пауки одержали в ней верх лишь потому, что научились понимать человеческие мысли» [6, с. 100]. Сравнив позиции людей на карте мира пауков в прошедшем и настоящем времени, Найл убеждается в существовании внутренних истоков зла в человеческом сообществе, но находит и возможность для их пресечения в тех гуманистических ценностях, которые защищены непроницаемыми стенами Белой башни от посягательств пауков и недостойных людей.

Жизненная стезя героя сплелась с общей линией человеческого бытия в бесчеловечном мире после того, как смертоносцы захватили юношу в плен, убив отца и обратив в рабство других членов семьи. Это трагическое событие дает начало череде эпизодов и происшествий, составляющей сюжетно-драматическую основу пути протагониста. Подобно другим своим сородичам, Найлу довелось пережить животный страх в когтистых лапах смертоносца, отчаяние бесправного узника, тяжесть подневольного труда. Однако, в отличие от них, он сумел найти неторную тропу выхода из состояния господства и подчинения благодаря редкостным способностям ума и интуиции и целеустремленной воле к их совершенствованию: «Овладей люди навыками внедряться и управлять мыслями, дни паучьего господства окажутся сочтены. Как какоенибудь дрессированное насекомое, закабаленный разум - это замок, к которому подходят несколько ключей» [6, с. 317]. Шведский исследователь К.Г. Бергстрём полагает, что для К. Уилсона главным фактором решения гуманитарных проблем является реализация скрытых ресурсов сознания: «Это дорога к внутренней свободе и силе, ключ к человеческим возможностям» [8, p. 143]. Однако в романе ключевая сцена исхода из мира насилия отмечена не вспышкой озарения сознания, а моментом нравственного выбора между недостойной жизнью по законам пауков и смертельным риском во имя законов человечности. Найл отказывается от предательского сговора с пауками против инакомыслящих людей, но спасается от жестокой казни за неповиновение в стенах Белой башни, которая не открывала их ни для кого прежде.

С проникновением героя в «ментальный замок» сюжетное движение замедляется, и драматическое повествование сменяется эпическим описанием естественной и общественной истории мира пауков. Французский структуралист Ж. Женетт отчетливо разграничивает два вида дискурса по признакам их жанрообразующих функций в системе пространственных и временных координат произведения: «Повествование занято поступками и событиями как чистыми процессами, а потому делает акцент на темпорально-драматической стороне рассказа; описание же, напротив, задерживая внимание на предметах в их симультанности и даже их процессы рассматривая как зрелища, словно приостанавливает ход времени и способствует развертыванию рассказа в пространстве» [2, с. 291]. Жанровая организация текста в романе «Башня» отвечает приведенному определению, но с той оговоркой, что обе формы литературного письма здесь равно причастны к авторской стратегии глобализации художественного мира и эстетической деятельности героя. В драматическом повествовании мир подает себя герою, вовлекая в действие и увеличивая поле его умственного видения по мере накопления опыта и с течением времени. В эпическом описании, когда герой осваивает научное и культурное наследие предков в «ментальном замке», картина мира и человека в нем приобретает глобальные масштабы благодаря усвоенному навыку субъекта воспринимать объективную реальность в широком горизонте сознания. Если главным достижением стези опыта явилось усвоение этического принципа человеческого бытия, то из уроков научного знания во время остановки в пути герой извлекает правило эволюционного процесса всего сущего на Земле. Сделанные открытия давали исчерпывающее объяснение сложившемуся порядку вещей: пауки превзошли всех прочих обитателей планеты, потому что жили по законам естественной эволюции и сделали 
огромный скачок в своем развитии после великой космогенной катастрофы; люди же потерпели сокрушительное поражение в битве за первенство, поскольку нарушили моральный закон своего единства. С этими идеями Найл покидает Белую башню и возвращается в мир пауков, чтобы ответить на вызов императива долга: «Закон жизни гласит: выживает сильнейший. Если вам не по силам одолеть смертоносцев, значит вы недостойны свободы, а пауки имеют право на то, чтобы и впредь властвовать над Землей» $[6$, c. 390].

По возвращении героя на стезю опыта эпическое пространство приобретает социальные измерения. Нелегальное положение опасного вольнодумца обрекало Найла на участь бесприютного скитальца и, вместе с тем, создавало возможность единого видения многообразных сторон жизни, а также способов ее общественной и государственной организации в империи пауков. В образовавшейся перспективе возникает картина классового общества, включающего в себя смешанные элементы исторических формаций, но равномерно пронизанного силовыми линиями тоталитарной власти на всех уровнях иерархии. Поскольку насильственное отчуждение свободы было испытано Найлом как отсутствие фундаментального условия человеческого существования, то он выходит на арену открытой борьбы с тоталитаризмом вместе с единомышленниками из числа рабочих, готовых отстаивать свои насущные интересы в отношениях с паучьей аристократией и буржуазным сословием жуков-бомбардиров. Однако протестные акции перерастают в кровопролитие такого масштаба, что антагонисты могли истребить друг друга, если бы обоюдное возмущение нравственного сознания и здравого смысла не заставили их искать мирного соглашения. Найл был привлечен к судебной ответственности как главный зачинщик беспорядков и приговорен к изгнанию по решению суда, который принял во внимание компромиссный договор враждующих сторон и бескомпромиссное обвинение пауков в посягательстве людей на предустановленные основы мироустройства: «Они не способны жить в мире. В конце концов боги устали от них и сделали хозяевами нас. И с той поры Земля живет в мире» [6, c. 553].

Перед изгнанником простирался долгий путь к пониманию того, что закон естественной эволюции распространяется на общественную жизнь, а принцип этической целостности бытия объединяет всех живых существ в моральный универсум на планете. Открытие и постижение этих истин составляли новые этапы опыта и знания, которые подлежали художественному описанию и философскому осмыслению в глобальной эпической перспективе «Мира пауков».

$$
* * *
$$

1. Барт Р. Мифологии / Пер. с фр. С. Зенкина. - 3-е изд. - М.: Академический проект, 2014. - 351 с.

2. Женетт Ж. Фигуры. В 2-х томах. Т. 1 - М.: Изд-во им. Сабашниковых, 1988. - 472 с.

3. Ролстон Ш. Х. Существует ли экологическая этика? / Глобальные проблемы и человеческие ценности / Пер. с фр. и англ. / Сост. Л И. Василенко, В. Е. Ермолаева. - М.: Прогресс, 1990. С. 258-288.

4. Ковтун Е. Поэтика необычайного. Художественные миры фантастики, волшебной сказки, утопии, притчи и мифа. (На материале европейской литературы первой половины XX века). М.: Изд-во МГУ, 1999. $-306 \mathrm{c}$.

5. Турчин А. В., Батин М. А. Футурология/ХХІвек. Бессмертие или глобальные катастрофы? - М.: БИНОМ. Лаборатория знаний, 2013. - 263 с.

6. Уилсон К. Мир пауков. Кн. 1. Башня / Пер. с англ. А. Шабрина. - М.: Эксмо; СПб.: Домино, 2010. - 560 c.

7. Фуко М. Слова и вещи. Археология гуманитарных наук / Пер. с фр. В.П. Визгина, Н. С. Автономовой. СПб.: Изд-во А-cad, 1994. - 406 с.

8. Bergström G. An Odyssey to Freedom: Four themes in Colin Wilson's novels / Acta Universitatis Uppsalientis. 47. - Uppsala, Stockholm: University of Uppsala, 1983. 160 p.

9. Wilson C. Beyond the Outsider. - London: Pan Books, 1966. - 255 p.

10. Wilson C. The Philosopher's Stone. - London: Baker, 1969. - 315 p.

11. Wilson C. The World of Violence. - Boston: Houghton Mifflin Co., 1963. 272 p. 